\title{
JunD/HBZ enhances HBZ enhances HTLV-1 antisense transcription
}

\author{
Jean-Marie Peloponese ${ }^{1 *}$, Isabelle Lemasson², Benoit Barbeau ${ }^{3}$, Jean-Michel Mesnard ${ }^{1}$ \\ From 15th International Conference on Human Retroviruses: HTLV and Related Viruses \\ Leuven and Gembloux, Belgium. 5-8 June 2011
}

Human T-cell leukemia virus type 1 (HTLV-1) is an oncogenic retrovirus etiologically causal of adult $\mathrm{T}$-cell leukemia (ATL). ATL is a highly virulent cancer that is resistant to chemotherapeutic treatments. To understand this disease better, it is important to comprehend how HTLV-1 promotes cellular growth and survival. The human $\mathrm{T}$-cell leukemia virus type 1 (HTLV-1) basic leucine zipper factor (HBZ) gene is encoded by the minus strand of the HTLV-1 provirus and transcribed from the 3' long terminal repeat (LTR). HBZ expression promotes proliferation and survival of HTLV-1 infected cells in vivo. Although previous reports have been aimed at understanding the potential role of HBZ in HTLV-1 pathogenesis, little is known as to how this viral gene is regulated in ATL cells. Here using our K30-3'asLuc reporter construct, we show that HBZ protein upregulates antisense transcription. Generation of stable clones in $293 \mathrm{~T}$ cells confirm that HBZ stimulates antisense transcription from the 3' LTR through its interaction with JunD, an AP-1 protein, and its action on the $\mathrm{Sp} 1$ binding site located in the 3'LTR. Our results suggest that in vivo inhibition of JunD could be a possible new therapeutic strategy in ATL treatment.

\section{Author details \\ ${ }^{1}$ Centre d'études d'agents Pathogènes et Biotechnologies pour la Santé (CPBS), CNRS/UM1/UM2 UMR 5236, Montpellier, France. ${ }^{2}$ East Carolina University, Department of Microbiology and Immunology, Greenville, North Carolina, 27834, USA. ${ }^{3}$ Université du Québec à Montréal, Département des sciences biologiques, Montréal (Québec) Canada, H2X 3X8.}

Published: 6 June 2011

\footnotetext{
* Correspondence: jean-marie.peloponese@cpbs.cnrs.fr

${ }^{1}$ Centre d'études d'agents Pathogènes et Biotechnologies pour la Santé (CPBS), CNRS/UM1/UM2 UMR 5236, Montpellier, France Full list of author information is available at the end of the article
}

doi:10.1186/1742-4690-8-S1-A135

Cite this article as: Peloponese et al:: JunD/HBZ enhances HBZ enhances HTLV-1 antisense transcription. Retrovirology 2011 8(Suppl 1):A135.
Submit your next manuscript to BioMed Central and take full advantage of:

- Convenient online submission

- Thorough peer review

- No space constraints or color figure charges

- Immediate publication on acceptance

- Inclusion in PubMed, CAS, Scopus and Google Scholar

- Research which is freely available for redistribution

\section{() Biomed Central}

C Biomed Central 